\title{
Isolating The Key Variables For Regression Models In Enterprise Software Acquisition Decisions: A Blocking Technique
}

Rolando Pena-Sanchez, (Email: rsanchez@tamiu.edu), Texas A\&M International University Jacques Verville, (Email: jverville@tamiu.edu), Texas A\&M International University

Christine Bernadas, (Email: cbernadas@tamiu.edu), Texas A\&M International University

\begin{abstract}
Often researchers in the field of information systems face problems related to the variable selection for model building; as well as difficulties associated to their data (small sample and/or non normality). The goal of this article is to present an original statistical blocking-technique based on relative variability for screening of variables in multivariate regression models. We applied the blocking-technique and a nonparametric bootstrapping method to the data collected on the USASouth border for a research concerning enterprise software (ES) acquisition contracts. Three mutually exclusive blocks of relative variability for the response variables were formed and their corresponding regression models were built and explained. A conclusion was drawn about the decreasing tendency on the adjusted coefficient of determination $\left(R_{\text {adj }}^{2}\right)$ magnitudes when the blocks change from low $(L)$ to high $(H)$ condition of relative variability. The obtained models (via stepwise regression) exhibited significant p-values (0.0001).
\end{abstract}

\section{INTRODUCTION}

$\mathrm{n}$ this research we present an original statistical blocking-technique based on relative variability to support the screening of variables for multivariate regression models. We applied such blocking-procedure and a nonparametric bootstrapping method (Pena-Sanchez, 2005a) to analyze the data collected from the USASouth border for a research concerning enterprise software (ES) acquisition contracts. Researchers are often faced with small samples where data does not meet the requirements for conventional (parametric) statistical methods. The reason could be due to conceptual problems (Pullman and Eaton, 2001), low turn out rate from participants in laboratory experiments, or low responses from mail surveys and/or other issues related to the difficulty of collecting data (Leedy and Ormrod, 2001). In the past decade or so, bootstrapping has proven to be a popular method for small sample size data sets. It has been widely used in such fields as astronomy, biology, economics, engineering, finance, medicine, molecular biology and genetics; however, it has not been widely used within the field of information systems or business management as a whole.

What is bootstrapping? Bootstrapping is the concept of re-sampling data randomly multiple times and drawing statistical conclusions from the data set. Bootstrapping was instigated by Efron (1979). It can be used in a wide variety of scenarios. For example; bootstrapping can correctly estimate the variance of sample median; it also can estimate the error rates in a linear discrimination problem, out performing "cross-validation," another nonparametric estimation method (Efron, 1979). The bootstrapping method is susceptible to help researchers to overcome some of their data problems and find interesting results when other traditional techniques can't be used. 


\section{DATA AND METHODOLOGY}

\subsection{Data}

The research used as example was carried out with a random sample of 52 (multivariate) observations from the USA-South border around Laredo, Texas (Web County) during summer 2004. The data was collected via a mail survey sent to IT executives in charge of ES contracting; the survey questionnaire (Appendix B) was developed based on a previous research project on ES acquisition practices (Verville, 2000). A small pilot study, conducted with 30 respondents, was used to pre-test the instrument and to identify any ambiguities and other problems with the survey questionnaire. The survey had 36 questions (named X1 to X36) and to answer the respondents use a Likert response scale from 1 to 7 from "not very important" (1) to "very important" (7). The descriptive labels for each of the 36 variables are shown in the Appendix A.

\subsection{Methodology}

We divided the methodology in three phases:

1) Hypothesis Testing, described in Section 2.2.1, tests the differences among central location parameters for all response-variables via nonparametric procedures (see Table 3).

2) Bootstrapping Method, described in Section 2.2.2, is technique for estimating the relative variability (coefficient of variation) for all response-variables X1 to X36 (see Table 6).

3) A Blocking Technique, described in Section 2.2.3, is a procedure for conforming the "blocks of relative variability": low, moderated, and high (see Table 7). Thus, inside each block, the last step is to estimate the most significant models (Mood et al, 1974) of multiple linear regression via stepwise regression (see Table 8).

\subsubsection{Nonparametric Hypotheses Testing}

\subsubsection{The Kruskal-Wallis test}

This test is used under the assumption of independence between $\mathrm{k}$ samples $(\mathrm{k} \geq 3)$.

The involved hypotheses for the Kruskal-Wallis test are:

$\mathbf{H}_{\mathbf{0}}$ : All the k population distribution functions are equal.

$\mathbf{H}_{\mathrm{a}}$ : At least one the populations tend to yield larger observations than at least on the others populations.

Due to the sensitivity of this test about the differences between central location parameters in the populations, the alternative hypothesis may be stated as:

$\mathbf{H}_{\mathbf{a}}:$ The k populations do not all have equal central location parameters.

\subsubsection{The Friedman Test}

Under the Kruskal-Wallis test it is assumed that each "Executive" has been rating each variable (from $\mathrm{X}_{1}$ to $X_{36}$ ) in an independent way for each criterion: levels of $X_{38}$ (see Table 4) and/or $X_{45}$ (see Table 5); but taking in consideration the fact that the data are composed by related samples (Pohlen and Coleman 2005), given that for each criterion, the 36 ratings (one rating for each variable) belong to the same "Executive"; thus, there is a link among the 36 responses: "Executive"; then, independence is no longer valid. Therefore the appropriated statistical contrast for this case is the Friedman test, using "Executive" as a blocking factor.

The involved hypotheses in the case of the Friedman test, (given b blocks (Executives) and $k$ treatments $\left(\mathrm{X}_{38}\right.$ and/or $\left.\mathrm{X}_{45}\right)$ ) also called "control factors" (Pena-Sanchez, 2005b) are: 
$\mathbf{H}_{\mathbf{0}}$ : Each ranking of the random variables within a block is equally probable; which is equivalent to say: The location parameters $\square_{\mathrm{i}}$ are equal within each block $\mathrm{j}$; where $\mathrm{i}=1,2, \ldots, \mathrm{k} ; \mathrm{j}=1,2, \ldots, \mathrm{b}$

$\mathbf{H}_{\mathbf{a}}$ : At least one of the groups of classification (treatments: levels of $\mathrm{X}_{38}$ and/or $\mathrm{X}_{45}$ ) tended to yield larger observations than at least one of the other groups of classification; which is equivalent to say that at least one of the location parameters $\square_{\mathrm{i}}$ is not equal to the others within at least one block.

\subsubsection{Bootstrapping Method}

This is a resampling technique, in which the original data are repeatedly sampled with replacement to generate a large bootstrap sample for model estimation (see Table 1). Thus, the confidence interval estimates for the parameters are no longer evaluated under statistical assumptions, but instead are calculated using the bootstrapped (empirical) observations.

Table 1

Steps of the bootstrapping technique

\begin{tabular}{|l|l|}
\hline \multicolumn{1}{|c|}{ Step } & \multicolumn{1}{c|}{ Action } \\
\hline 1. Read observations $\left\{\mathrm{x}_{1}, \mathrm{x}_{2}, \ldots, \mathrm{x}_{\mathrm{n}}\right\}$ Data & Imports the $\mathrm{n}$ observations and save these as the 'Data' vector. \\
\hline 2. Repeat $\mathrm{m}, \mathrm{m} \geq 100$ & Repeat the next steps $\mathrm{m}$ times. \\
\hline 3. Sample $\mathrm{n}$ Data: Output & $\begin{array}{l}\text { To sample } \mathrm{n} \text { observations with replacement. } \\
\text { The output represents the bootstrap sample. }\end{array}$ \\
\hline 4. Mean of Output: Value1 & $\begin{array}{l}\text { Find the mean of the vector Output and save its value as } \\
\text { Value1 }\end{array}$ \\
\hline 5. Track Value1: Total & $\begin{array}{l}\text { To keep track of the result of each simulation, this is attached } \\
\text { into the Total vector. }\end{array}$ \\
\hline 6. End & $\begin{array}{l}\text { Ends a loop, and send the process back to a 'Repeat' } \\
\text { statement. }\end{array}$ \\
\hline 7. Global mean of Value1: $\mathrm{M}$ & $\begin{array}{l}\text { To evaluate the mean of all Value1, and save this as } \mathrm{M}, \text { which } \\
\text { is the bootstrapped mean (point) estimate for }\end{array}$ \\
\hline 8. Total: Percent $\left(\mathrm{P}_{\mathrm{L}}=2.5, \mathrm{P}_{\mathrm{U}}=97.5\right)$ & $\begin{array}{l}\text { Find 2.5 } \\
\text { which represents the lower and upper limits of a bootstrapped } \\
95 \% \text { confidence interval estimate for }\end{array}$ \\
\hline 9. Write: Output, Value1, $\mathrm{M}, \mathrm{P}_{\mathrm{L}}$ and $\mathrm{P}_{\mathrm{U}}$ & \begin{tabular}{l} 
Exports the results. \\
\hline
\end{tabular} \\
\hline
\end{tabular}

\subsubsection{A Blocking Technique}

Three blocks of relative variability: low, moderated, and high; have been conformed (see Table 7). The conformation criterion is based on the relative variability of the data (X1 to X36) through its coefficient of variation: $\mathrm{CV}(\mathrm{Xi})_{\%}=($ Standard deviation of Xi / Mean of Xi) $100 \%$.

Criteria: Block L: Low $\left(\mathrm{CV}_{\%}<\mathrm{Q}_{1}\right)$, Block M: Moderated $\left(\mathrm{Q}_{1} \leq \mathrm{CV}_{\%} \leq \mathrm{Q}_{3}\right)$, and Block H: High $\left(\mathrm{CV}_{\%}>\mathrm{Q}_{3}\right)$.

Where $\mathrm{Q}_{1}$ and $\mathrm{Q}_{3}$ represent the first (25\%) and the third quartile (75\%) respectively. $\mathrm{Q}_{1}$ is also named as the twenty-five percentile, similarly $\mathrm{Q}_{3}$ represents the seventy-five percentile; all of this with respect to the total distribution of $\mathrm{CV}_{\%}$.

Thus, Block L contains a set of response variables with high stability and/or low (L) relative variability; while Block $\mathrm{H}$ contains a set of response variables with low stability and/or high $(\mathrm{H})$ relative variability. The group of variables with a condition of moderated stability and/or a moderated (M) relative variability is contained in Block $\mathrm{M}$. This notion of "stability" is based upon the ordered measures (quartiles) of the coefficient of variation $\left(\mathrm{CV}_{\%}\right)$. As we can perceive, the response variables have been grouped in mutually exclusive blocks of relative variability. 
After this conformation of blocks, the last step is to estimate (for each block) the most significant models (Mood et al, 1974) of multiple regressions via stepwise regression (see Table 8).

\section{RESULTS}

Given the limited number of observations ( $\mathrm{n}=52$ ), the fact that many variables do not meet parametric F-test assumptions like normality (Kolmogorov-Smirnov test), and the recognition that some of them do not meet homocedasticity (Levene test) of the variances (see Table 2), then the use of a nonparametric statistical method based on ranks (Conover, 1999), such as the Friedman test described in the Section 2.2.1.2 is justified.

Table 2

Kolmogorov-Smirnov test for normality, and Levene test for homogeneity of variances (homocedasticity)

\begin{tabular}{|l|c|c|}
\hline \multicolumn{1}{|c|}{ Variables } & Test and p-values & Decision \\
\hline $\mathrm{X} 1$ to X6, X8 to X13, & Kolmogorov-Smirnov \\
X15, X17 to X32, & p-values $<0.05$ & \\
X34 to X36 & & \\
\hline X7, X21, X27, X28, X31 & Levene p-values $<0.05$ & Reject Homocedasticity \\
\hline
\end{tabular}

Table 3

Friedman test for the equality of location parameters

\begin{tabular}{|c|c|c|}
\hline Variables & Friedman's test p-value & Decision \\
\hline $\mathrm{X} 1$ to $\mathrm{X} 36$ & $>0.05$ & Do not Reject $\mathrm{H}_{\mathrm{o}}$ \\
\hline
\end{tabular}

Table 4

Frequency distribution for X38: What is your job title/area of responsibility?

\begin{tabular}{l|c|c|}
\hline $\begin{array}{c}\text { X38 What is your job title/area of } \\
\text { responsibility? }\end{array}$ & Frequency & Percent \\
\hline IT Management & 2 & 3.8 \\
Purchasing & 6 & 11.5 \\
Legal & 3 & 5.8 \\
User & 12 & 23.1 \\
Other & 29 & 55.8 \\
Total & $\mathbf{5 2}$ & $\mathbf{1 0 0 . 0}$ \\
\hline
\end{tabular}

Table 5

Frequency distribution for X45: What is your Job/area of responsibility?, where the first 3 categories in Table 4 have been

\begin{tabular}{|l|c|c|}
\hline $\begin{array}{l}\text { X45: What is your Job/area of } \\
\text { responsibility? }\end{array}$ & Frequency & Percent \\
\hline $\begin{array}{l}\text { CIO, IT Management, Purchasing, } \\
\text { and/or Legal }\end{array}$ & 11 & 21.2 \\
\hline User & 12 & 23.1 \\
\hline $\begin{array}{l}\text { Other: Advisor, Consultant, and/or } \\
\text { External Contractor }\end{array}$ & 29 & 55.8 \\
\hline Total & $\mathbf{5 2}$ & $\mathbf{1 0 0 . 0}$ \\
\hline
\end{tabular}

Table 2 justifies the use of nonparametric statistics (p-values $<0.05$ ), also Table 3 indicates that according to the Friedman test: All location parameters $\left(\square_{1}\right.$ to $\left.\square_{36}\right)$ do not show a significant difference (p-values $\left.>0.05\right)$ among the 3 types of Job/area of responsibility defined by the variable X45 in Table 5. We got the same conclusion (pvalues $>0.05$ ) among the 5 types of Job-title/area of responsibility defined by the variable X38 in Table 4 . Thus, Tables 4 and 5 contain the treatments (categories) required in the Friedman test; the other elements or components in this test 
are: data (response variables X1 to x36) and the blocking factor: Executives. Unfortunately we don't have sufficient sampling evidence or more information to reject the null hypothesis $\left(\mathrm{H}_{\mathrm{o}}\right)$ presented in the section 2.2.1.2.

Knowing that the sample size was relatively small to go forward with the confidence interval estimates (Morrison, 2005), we decided to use the bootstrapping technique described in Table 1, to generate a large sample from the original distribution of the 52 multivariate observations; the results are shown in Table 6 .

Table 6

Bootstrapped estimates according to the syntax described in Table 1 . Notation: $\mathbf{X}_{\mathrm{C}}$ : Variable ${ }_{\text {condition}}, \bar{X}:$ mean, $\mathrm{S}:$ Std. Deviation, $\mathrm{CV}_{\%}$ : Coefficient of Variation in percent, $L_{95}$ : Lower limit, and $U_{95}$ : Upper limit of the $95 \%$ Confidence Interval

\begin{tabular}{|c|c|c|c|c|c|c|c|c|c|c|c|}
\hline $\mathbf{X}$ & $\bar{X}$ & $\mathbf{S}$ & $\mathbf{C V}_{\boldsymbol{\%}}$ & $\mathbf{L}_{\mathbf{9 5}}$ & $\mathbf{U}_{\mathbf{9 5}}$ & $\mathbf{X}$ & $\bar{X}$ & $\mathbf{S}$ & $\mathbf{C V}_{\boldsymbol{\%}}$ & $\mathbf{L}_{\mathbf{9 5}}$ & $\mathbf{U}_{\mathbf{9 5}}$ \\
\hline $\mathrm{X} 1_{\mathrm{M}}$ & 5.74 & 1.19 & 20.76 & 17.40 & 24.13 & $\mathrm{X} 19_{\mathrm{H}}$ & 5.58 & 1.41 & 25.21 & 20.19 & 30.92 \\
\hline $\mathrm{X} 2_{\mathrm{H}}$ & 5.39 & 1.40 & 25.94 & 20.74 & 31.38 & $\mathrm{X} 20_{\mathrm{M}}$ & 5.31 & 1.33 & 25.04 & 20.18 & 30.10 \\
\hline $\mathrm{X} 3_{\mathrm{M}}$ & 5.89 & 1.17 & 19.79 & 16.99 & 22.70 & $\mathrm{X} 21_{\mathrm{H}}$ & 5.75 & 1.46 & 25.44 & 19.75 & 31.18 \\
\hline $\mathrm{X} 4_{\mathrm{M}}$ & 5.65 & 1.23 & 21.78 & 16.45 & 27.16 & $\mathrm{X} 22_{\mathrm{H}}$ & 5.56 & 1.42 & 25.56 & 20.87 & 29.92 \\
\hline $\mathrm{X} 5_{\mathrm{M}}$ & 5.54 & 1.26 & 22.67 & 18.83 & 26.72 & $\mathrm{X} 23_{\mathrm{L}}$ & 5.75 & 1.06 & 18.47 & 15.16 & 22.28 \\
\hline $\mathrm{X} 6_{\mathrm{M}}$ & 5.64 & 1.17 & 20.71 & 16.47 & 25.77 & $\mathrm{X} 24_{\mathrm{L}}$ & 5.97 & 1.03 & 17.29 & 14.04 & 20.34 \\
\hline $\mathrm{X} 7_{\mathrm{M}}$ & 5.56 & 1.23 & 22.04 & 17.98 & 26.23 & $\mathrm{X} 25_{\mathrm{M}}$ & 5.75 & 1.26 & 21.85 & 17.05 & 27.15 \\
\hline $\mathrm{X} 8_{\mathrm{M}}$ & 5.45 & 1.25 & 23.02 & 18.09 & 28.27 & $\mathrm{X} 26_{\mathrm{M}}$ & 5.37 & 1.27 & 23.62 & 20.63 & 26.81 \\
\hline $\mathrm{X} 9_{\mathrm{H}}$ & 5.54 & 1.53 & 27.56 & 22.01 & 33.08 & $\mathrm{X} 27_{\mathrm{M}}$ & 5.44 & 1.24 & 22.76 & 17.84 & 28.47 \\
\hline $\mathrm{X} 10_{\mathrm{H}}$ & 5.18 & 1.74 & 33.54 & 27.51 & 40.21 & $\mathrm{X} 28_{\mathrm{L}}$ & 5.62 & 1.02 & 18.13 & 15.68 & 20.40 \\
\hline $\mathrm{X} 11_{\mathrm{M}}$ & 5.96 & 1.18 & 19.78 & 15.01 & 25.54 & $\mathrm{X} 29_{\mathrm{L}}$ & 5.98 & 1.08 & 18.06 & 13.87 & 22.44 \\
\hline $\mathrm{X} 12_{\mathrm{M}}$ & 5.58 & 1.30 & 23.30 & 17.82 & 29.03 & $\mathrm{X} 30_{\mathrm{L}}$ & 5.94 & 0.946 & 15.94 & 13.35 & 18.65 \\
\hline $\mathrm{X} 13_{\mathrm{L}}$ & 5.94 & 1.02 & 17.22 & 12.21 & 23.26 & $\mathrm{X} 31_{\mathrm{L}}$ & 5.99 & 0.940 & 15.68 & 13.03 & 18.66 \\
\hline $\mathrm{X} 14_{\mathrm{H}}$ & 4.94 & 1.55 & 31.29 & 25.93 & 36.69 & $\mathrm{X} 32_{\mathrm{L}}$ & 6.15 & 0.791 & 12.84 & 11.14 & 14.48 \\
\hline $\mathrm{X} 15_{\mathrm{H}}$ & 5.16 & 1.54 & 29.85 & 23.43 & 36.87 & $\mathrm{X} 33_{\mathrm{M}}$ & 5.33 & 1.31 & 24.61 & 20.70 & 28.48 \\
\hline $\mathrm{X} 16_{\mathrm{M}}$ & 5.35 & 1.30 & 24.26 & 20.02 & 29.30 & $\mathrm{X} 34_{\mathrm{M}}$ & 5.73 & 1.07 & 18.71 & 15.01 & 23.02 \\
\hline $\mathrm{X} 17_{\mathrm{H}}$ & 5.32 & 1.37 & 25.83 & 19.98 & 32.26 & $\mathrm{X} 35_{\mathrm{M}}$ & 5.75 & 1.36 & 23.71 & 18.77 & 29.18 \\
\hline $\mathrm{X} 18_{\mathrm{M}}$ & 6.02 & 1.17 & 19.52 & 14.80 & 25.13 & $\mathrm{X} 36_{\mathrm{L}}$ & 6.17 & 0.973 & 15.76 & 13.09 & 18.64 \\
\hline
\end{tabular}

Thus, the set of 36 response-variables can be grouped in 3 mutually exclusive subsets of bootstrapped relative variability (condition): L: low $\left(\mathrm{CV}_{\%}<\mathrm{Q}_{1}\right)$, $\mathrm{M}$ : moderated $\left(\mathrm{Q}_{1} \leq \mathrm{CV}_{\%} \leq \mathrm{Q}_{3}\right)$, and $\mathrm{H}$ : high $\left(\mathrm{CV}_{\%}>\mathrm{Q}_{3}\right)$. Where the first quartile is $\mathrm{Q}_{1}=18.53$, and the third quartile is $\mathrm{Q}_{3}=25.17$. The blocks with the variables grouped under this criterion are shown in (Table 7), while the blocks with the variables' labels appear in Appendix A.

Table 7

Blocks of response variables in terms of stability and/or relative variability

\begin{tabular}{|c|c|c|}
\hline $\begin{array}{c}\text { Block } L \\
\text { Response variables with high stability } \\
\text { and/or low }(\mathrm{L}) \text { relative variability } \\
\left(\mathbf{C V} V_{\%}<Q_{1}\right)\end{array}$ & $\begin{array}{c}\text { Block } M \\
\text { Response variables with moderated } \\
\text { stability and/or moderated }(M) \\
\text { relative variability } \\
\left(Q_{1} \leq \mathrm{CV} \% \leq Q_{3}\right)\end{array}$ & $\begin{array}{c}\text { Block } H \\
\text { Response variables with low stability } \\
\text { and/or high }(\mathbf{H}) \text { relative variability } \\
\left(\mathrm{CV}_{\%}>\mathbf{Q}_{3}\right)\end{array}$ \\
\hline $\begin{array}{c}\mathrm{X} 13, \mathrm{X} 23, \mathrm{X} 24, \mathrm{X} 28, \mathrm{X} 29, \mathrm{X} 30, \mathrm{X} 31 \\
\mathrm{X} 32, \mathrm{X} 36\end{array}$ & $\begin{array}{c}\mathrm{X} 1, \mathrm{X} 3, \mathrm{X} 4, \mathrm{X} 5, \mathrm{X} 6, \mathrm{X} 7, \mathrm{X} 8, \mathrm{X} 11, \mathrm{X} 12, \\
\mathrm{X} 16, \mathrm{X} 18, \mathrm{X} 20, \mathrm{X} 25, \mathrm{X} 26, \mathrm{X} 27, \mathrm{X} 33 \\
\mathrm{X} 34, \mathrm{X} 35\end{array}$ & $\begin{array}{c}\mathrm{X} 2, \mathrm{X} 9, \mathrm{X} 10, \mathrm{X} 14, \mathrm{X} 15, \mathrm{X} 17, \mathrm{X} 19, \\
\mathrm{X} 21, \mathrm{X} 22\end{array}$ \\
\hline
\end{tabular}


The first block (L) contains variables where the respondents show a consensus among their opinions about the importance of these variables in ES acquisition contracts; while the block $\mathrm{M}$ contains variables related to contingencies and contractual assurances. The block $\mathrm{H}$ contains variables where the respondents manifest the fewest consensuses. By rotating all variables positions into each block and into each model via stepwise regression, Table 8 shows the best combination of independent variables: highest value of the adjusted coefficient of determination $\left(\mathrm{R}^{2}{ }_{\text {adj }}\right)$ for each block (see Table 8).

\section{Table 8}

Multiple regression models estimates per block of relative variability

\begin{tabular}{|c|c|c|c|c|c|c|}
\hline Block & $\begin{array}{c}\text { Dependent } \\
\text { variable }\end{array}$ & $\begin{array}{l}\text { Estimates of the } \\
\text { unstandardized } \\
\text { coefficients } \square_{\mathrm{x}} \text { for } \\
\text { the independent } \\
\text { Variables (x) }\end{array}$ & $\begin{array}{c}\text { Estimates of } \\
\text { the standardized } \\
\text { coefficients } \square{ }_{\mathrm{x}} \text { for } \\
\text { the independent } \\
\text { variables (x) }\end{array}$ & $\mathrm{R}_{\text {adj }}^{2}$ & $\underset{\text { statistic }}{\mathrm{F}}$ & p-value \\
\hline $\mathrm{L}$ & X23 & $\begin{aligned} \square_{\mathrm{OL}} & =-1.754 \\
\square_{24} & =0.283 \\
\square_{13} & =0.455 \\
\square_{30} & =0.263 \\
\square_{32} & =0.251\end{aligned}$ & $\begin{array}{l}\square{ }_{24}=0.274 \\
\square{ }_{13}=0.444 \\
\square{ }_{30}=0.233 \\
\square{ }_{32}=0.186\end{array}$ & 0.669 & 26.801 & 0.0001 \\
\hline M & X26 & $\begin{array}{c}\square \square_{0 \mathrm{M}}=0.554 \\
\square_{25}=0.596 \\
\square_{7}=0.364 \\
\square_{20}=-0.311 \\
\square_{35}=0.177\end{array}$ & $\begin{array}{c}\square{ }_{25}=0.595 \\
\square{ }_{7}=0.352, \\
\square{ }_{20}=-0.327 \\
\square{ }_{35}=0.190\end{array}$ & 0.632 & 22.884 & 0.0001 \\
\hline $\mathrm{H}$ & X17 & $\begin{aligned} \square & =0.141 \\
\square_{15} & =0.428 \\
\square_{22} & =0.276 \\
\square_{21} & =0.250\end{aligned}$ & $\begin{array}{l}\square{ }_{15}=0.476 \\
\square{ }_{22}=0.283 \\
\square{ }_{21}=0.265\end{array}$ & 0.554 & 22.147 & 0.0001 \\
\hline
\end{tabular}

We obtain in each block via stepwise regression a model (Figures 1 to 3), which maximize the significance of the data inside the blocks (significant p-values at 0.0001).

Figure 1

Model for block $L$ (block of low relative variability).

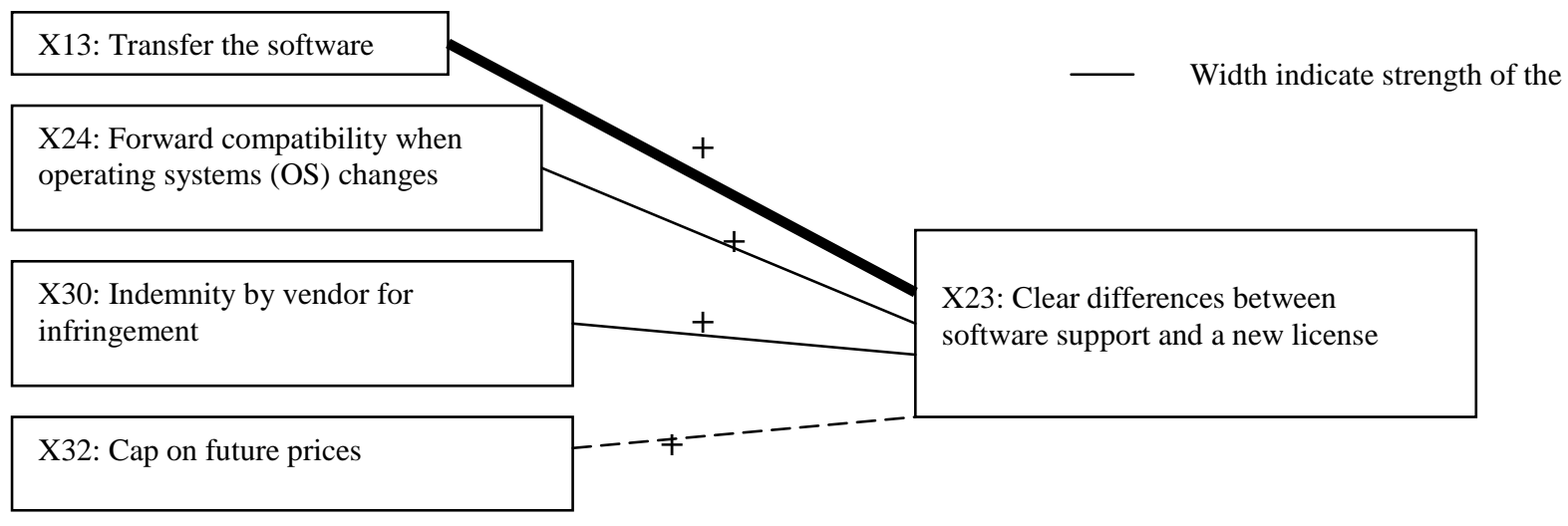

The four variables X13, X24, X30 and X32 contribute to the clarification between software support and new license (positive sign of the relationships). 
From their perspective, what is associated to normal changes (e.g. transfers or operating systems changes) should entail few or no costs for their company. Based on this view, the acquisition contract should clearly reflect this position and protect them to this effect. This contract should also prevent excessive increase in prices in case of new licenses. This point of view can be explained in part by the fact that USA-South border companies are medium and small enterprises. The acquisition of the ES has already put a strain on their budget; they want to insure that the rest of the ES life is as costless as possible.

Figure 2

Model for block M (block of moderated relative variability).

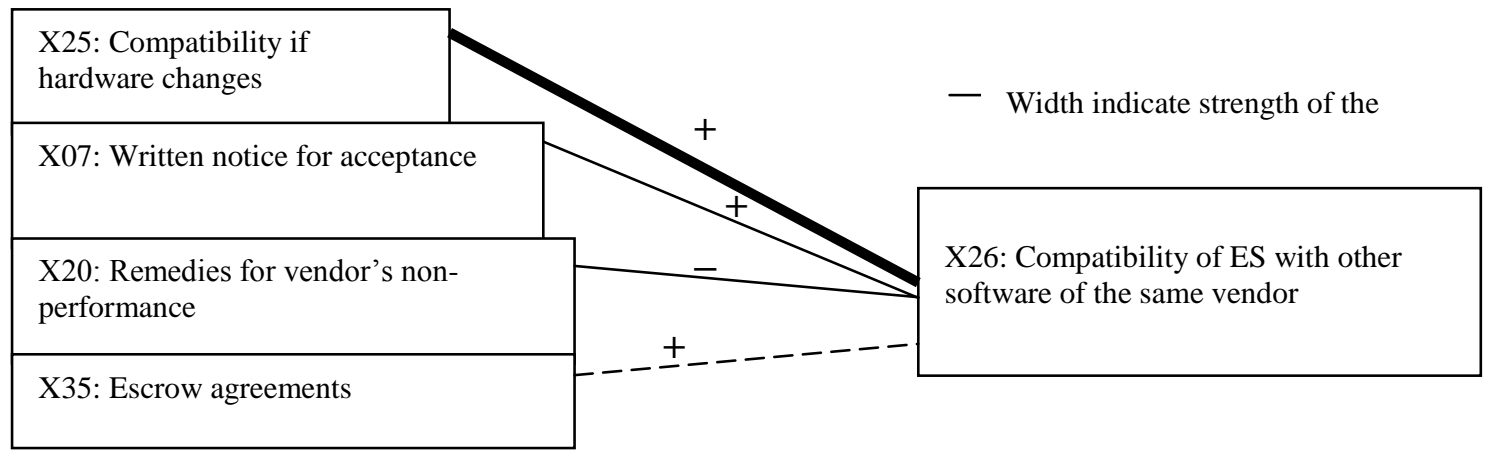

In this block, the independent variables are mainly oriented to the contingencies in the eventuality of relationships going wrong.

During the ES acquisition and particularly for USA-South border and Mexican companies, a strong relationship with a vendor is created (Verville et al., 2004). If a company is acquiring an ES from a specific vendor, there is a very high probability that they will continue to do business with this vendor (i.e. buy other software if they are available, no best-breed acquisition). Compatibility, written notice, remedies, and agreements are ways to formalize the link buyer-vendor, because the compatibility between products is a way to reinforce this link.

Figure 3

Model for block $\mathrm{H}$ (block of high relative variability).

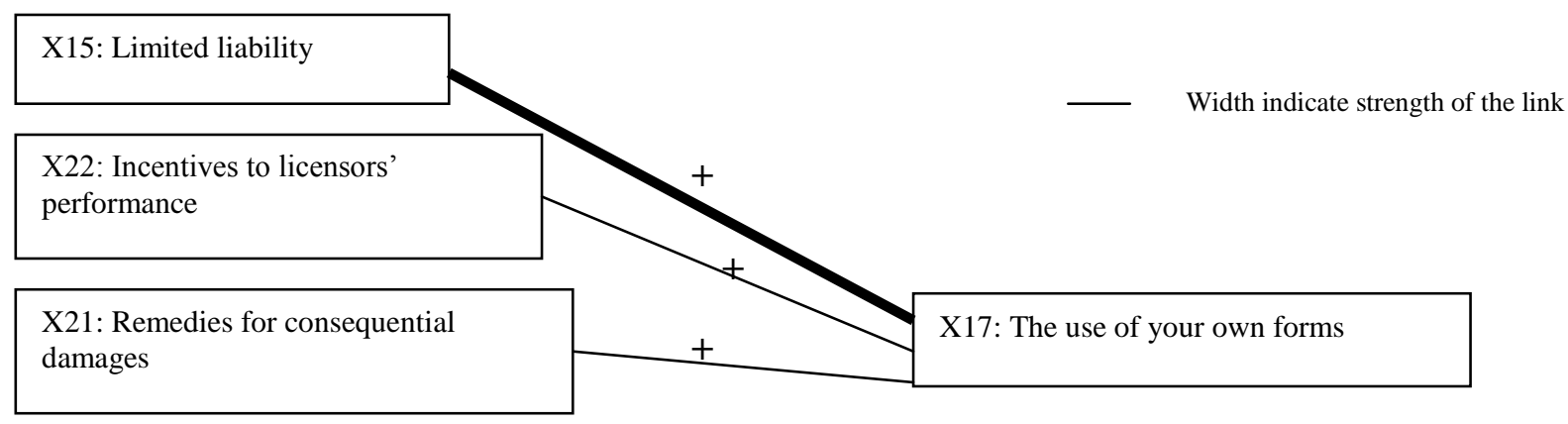

According to this model, the company, which will acquire an ES, should protect itself, and insure via the contract that it keeps the control. 


\section{CONCLUSIONS}

In this article, we have presented an original statistical blocking-technique based on the relative variability for screening of variables in multivariate regression models. We applied the blocking-technique and a nonparametric bootstrapping method to the data collected on the USA-South border for a research concerning enterprise software (ES) acquisition contracts. Before applying this method, the data collected were unusable through traditional statistical methods (due to small samples and non-normal data). Afterward, three mutually exclusive blocks of relative variability for the response variables were formed, and their regression models were built (Nishii, 1984) and explained. Thus, when the classical statistical methods are restricted by the size and type of data, the researchers can now follow new research avenues to confirm the results obtained. For example, from Table 8, we have drawn a conclusion about the decreasing tendency on the $\mathrm{R}^{2}$ adj magnitudes when the blocks change from low (L) to high (H) condition of relative variability. Then, a relevant result under this blocking technique was obtained: the three estimated models (through stepwise regression) exhibited significant p-values (0.0001).

Our conclusion from Figure 1, is that reviewing the block of independent variables (X13, X24, X30, and $\mathrm{X} 32$ ), the respondents in the USA-South border tend to associate strongly the responsibilities of the vendors linked with costs of changes or problems with a will to clearly specify what is supported (e.g. included in a maintenance/support contract) and what should be re-negotiated as a new license (X23).

From Figure 2, we conclude that the block of independent variables (X25, X07, and X35) tend to contribute to the contractual assurances regarding forward compatibility of the software with changes in other software from same vendor with the exception of "Remedies for vendor's non-performance" (X20), which presents a negative relationship with "The compatibility of ES with other software of the same vendor" (X26). Thus, for the respondents, the increase of remedies decreases their assurance regarding forward compatibility of the software with this other software of the same vendor. The sign can be explained by the fact that the formalization of the remedies in the contract is making the formalization of the compatibility with the vendor's software less important. This relationship and its sign will require further research (e.g. how can the sign be better explained? Is-it a specificity of USA-South border companies or with a USA wide or Mexican wide data with found the same relationship and sign?).

While the Figure 3 shows that the block of independent variables (X15, X22, and X21) re-enforce the will of the buyers to keep/use their own forms in place of the licensing contract (X17). Clearly, this model is more related to control. 


\begin{tabular}{|c|c|c|}
\hline \multicolumn{3}{|c|}{$\begin{array}{c}\text { Appendix } A \\
\text { Blocks of response-variables in terms of stability and/or relative variability condition } \\
\end{array}$} \\
\hline $\begin{array}{c}\text { Block } L \\
\text { Response variables with high stability } \\
\text { and/or low }(L) \text { relative variability } \\
\left(C V_{\%}<Q_{1}\right)\end{array}$ & $\begin{array}{c}\text { Block } M \\
\text { Response variables with moderated } \\
\text { stability and/or moderated }(M) \\
\text { relative variability } \\
\left(Q_{1} \leq \mathbf{C V} V_{\%} \leq Q_{3}\right)\end{array}$ & $\begin{array}{c}\text { Block } H \\
\text { Response variables with low stability } \\
\text { and/or high }(\mathbf{H}) \text { relative variability } \\
\left(\mathrm{CV}_{\%}>\mathrm{Q}_{3}\right)\end{array}$ \\
\hline $\begin{array}{l}\text { X13 In situations other than enterprise- } \\
\text { wide licenses, the right to transfer the } \\
\text { software to other equipment and operating } \\
\text { systems at no costs } \\
\text { X23 Contractually defined difference(s) } \\
\text { between (1) enhancements, releases, } \\
\text { versions, etc., that you receive by } \\
\text { subscribing to software support, and (2) } \\
\text { those the vendor insists are a new product } \\
\text { requiring a new license } \\
\text { X24 Contractual assurances regarding } \\
\text { forward compatibility of the software with } \\
\text { changes in operating systems (OS) } \\
\text { X28 Contingencies for what would occur } \\
\text { regarding support, upgrades, etc., should } \\
\text { the organization acquire another company } \\
\text { or divest a division, or if the vendor goes } \\
\text { bankrupt, other similar situations arise } \\
\text { X29 Vendor's responsibility to meet the } \\
\text { cost of procuring alternative third-party } \\
\text { support if the vendor fails to provide } \\
\text { adequate and timely service } \\
\text { X30 The vendor accepts to indemnify the } \\
\text { organization for all losses, damages or } \\
\text { liabilities arising from the infringement or } \\
\text { alleged infringement of such patents, } \\
\text { trademarks, trade secrets, copyrights or } \\
\text { any other pertaining to intellectual } \\
\text { property rights } \\
\text { X31 The vendor warrants that the services } \\
\text { provided to the organization shall not } \\
\text { infringe upon any patent, trademark, trade } \\
\text { secret, copyright, or any other right } \\
\text { relating to intellectual property: rights in } \\
\text { force, recorded, or recognized } \\
\text { X32 A cap on future maintenance prices } \\
\text { X36 Warranties and liabilities }\end{array}$ & $\begin{array}{l}\text { X1 The right to assign the software license } \\
\text { to a new corporate entity resulting from a } \\
\text { merger, consolidation, acquisition or } \\
\text { divestiture } \\
\text { X3 The right to assign the software license } \\
\text { to or allow the software to be used by an } \\
\text { outside entity if you outsource your data } \\
\text { processing operations } \\
\text { X4 The right to re-assign software licenses } \\
\text { within the corporate entity } \\
\text { X5 The right to develop and own } \\
\text { derivative works (i.e., code changes, } \\
\text { translation, adaptations, customizations) } \\
\text { based upon the software } \\
\text { X6 The right to customize during the } \\
\text { software acceptance period } \\
\text { X7 The right to define software acceptance } \\
\text { as occurring only upon your written notice } \\
\text { X8 The right to establish acceptance } \\
\text { procedure } \\
\text { X11 The right to terminate for } \\
\text { convenience } \\
\text { X12 The right to port the software to any } \\
\text { platform supported by the vendor at no or } \\
\text { minimum charge } \\
\text { X16 Prohibition against devices in the } \\
\text { software that control your compliance with } \\
\text { the software license } \\
\text { X18 Licenses that permit unlimited use } \\
\text { within your corporate or Organization } \\
\text { X20 Specific remedies for vendor's non- } \\
\text { performance } \\
\text { X25 Contractual assurances regarding } \\
\text { forward compatibility of the software with } \\
\text { changes in hardware } \\
\text { X26 Contractual assurances regarding } \\
\text { forward compatibility of the software with } \\
\text { changes in other software from the same } \\
\text { vendor } \\
\text { X27 Permission to exempt individual } \\
\text { employees/ contractors from signing } \\
\text { documents that acknowledge } \\
\text { confidentiality of software or to bind them } \\
\text { to terms of the license } \\
\text { X33 Avoidance of partial payments to } \\
\text { vendors based on checkpoints } \\
\text { X34 Insurance: the vendor agrees to } \\
\text { acquire and keep in force at its expense } \\
\text { insurance, comprehensive general liability } \\
\text { insurance, and workers compensation } \\
\text { insurance, and to provide evidence of such } \\
\text { insurance } \\
\text { X35 Escrow agreements (i.e., source or } \\
\text { obiect code access, etc., }\end{array}$ & $\begin{array}{l}\text { X2 The right to use the software for the } \\
\text { benefit of a business unit formerly within } \\
\text { your corporate organization which has } \\
\text { been sold } \\
\text { X9 The right to own the source code } \\
\text { (source code ownership) } \\
\text { X10 The right to terminate for } \\
\text { convenience } \\
\text { X14 In situations other than enterprise- } \\
\text { wide licenses, the right to use the software } \\
\text { for the benefit of other entities } \\
\text { X15 Limited liability for breach of your } \\
\text { obligations under the software license } \\
\text { agreement } \\
\text { X17 Use of your own form in place of the } \\
\text { licenser's form for licensing contracts } \\
\text { X19 License for any third-party software } \\
\text { application used under this contract: the } \\
\text { vendor guarantees that the organization } \\
\text { May use such software application without } \\
\text { infringing upon any third-party intellectual } \\
\text { property rights } \\
\text { X21 A remedy for consequential damages } \\
\text { that you suffer } \\
\text { X22 Incentives to licensors to reward their } \\
\text { performance in providing services }\end{array}$ \\
\hline
\end{tabular}




\section{REFERENCES}

1. $\quad$ Conover, W. J. (1999). Practical Nonparametric Statistics, 3rd. Edition John Wiley \& Sons.

2. $\quad$ Efron, B. (1979).Bootstrap Methods: Another Look at the Jackknife. The Annals of Statistics, 7, 1-26.

3. Leedy, P. D., and Ormrod, J. E. (2001). Practical Research: Planning and Design. Merryll Prentice Hall. Seventh Edition.

4. Mood, A. M., Graybill, F.A. and Boes, D. C. (1974). Introduction to the theory of statistics. McGraw-Hill. Third Edition.

5. Morrison, D. F. (2005). Multivariate Statistical Methods. $4^{\text {th }}$ Edition. Thomson Learning, Inc.

6. Nishii, R. (1984) Asymptotic properties of criteria for selection of variables in multiple regression. The Annals of Statistics. Vol. 12, No. 2. 758-765.

7. Pena-Sanchez, R. (2005a) A Nonparametric Comparison of the Per Capita Yearly Economic Needs for the Water Supply in the USA-Mexico Border Region. International Business and Economics Research Journal. 4(6), 35-46.

8. Pena-Sanchez, R. (2005b) A Case of Test-Results in RFID: A Technology to Improve Competitiveness in Logistics. American Society for Competitiveness. Competition Forum Vol. 3. pp. 98-107.

9. Pohlen, T. R. and Coleman, B. J. (2005). Evaluating Internal Operations and Supply Chain Performance Using EVA and ABC. Advanced Management Journal, 70(2), 45-59.

10. Pullman, M. E. and Eaton, F. F. (2001). Optimizing service attributes: The seller's utility problem. The Journal of the Decision Sciences Institute. 32(2), 251-275.

11. Verville, J. C. (2000) An empirical study of organizational buying behavior: a critical investigation of the acquisition of ERP software. Dissertation, Universite Laval, Quebec.

12. Verville, J. (2000) A Model of ERP Acquisition Process, Proceedings of the 31st Annual Conference of Decision Science Institute, November 2000.

13. Verville, J. (2000) The Acquisition Process for ERP Software: The Case of International Air. Proceedings of the 1st Global Information Technology Management (GITM) World Conference, June 2000.

14. Verville J., Flores O., and Bernadas C. (2004) Critical Factors Affecting the Selection Process of Enterprise Software: A Study of IS Managers Perceptions in the Mexican Service and Manufacturing Industries', Proceedings of the $21^{\text {st }}$ Annual Association of Management (AoM) Conference, Vol. 21, No. 2, pp 255-56. 